\title{
As pessoas do Pessoa e a religiosidade "fingida"
}

\author{
The people by Pessoa and \\ the religiosity simulated
}

\section{Anaxsuell Fernando da Silva}

Arquivo recebido em 29 de março de 2011 e aprovado em 15 de maio de 2011

V. 1 - N. 1 1을 Semestre de 2011

Doutorando em Ciências Sociais pela Universidade

Estadual de Campinas

(Unicamp). Mestre em Ciências Sociais, Bacharel em Sociologia e com licenciatura plena em Ciencias Sociais pela Universidade Federal

do Rio Grande do Norte (UFRN), também é graduado em Teologia pela Escola Superior de Teologia (EST/

RS) e Especialista em Educação Ambiental (IFESP). Atualmente é docente na

Pontifícia Universidade Católica de Campinas/SP. E, como pesquisador, dedica-se principalmente às temáticas relativas a Religião; Literatura e Arte; Epistemologia; Itinerário intelectual e Etnografia do saber.

\section{Resumo}

Fernando Pessoa (1888-1935) era um fingidor, ele mesmo advertira. Sua compreensão de Religião ia além dos limites sociais estabelecidos. O recurso da heteronímia que possibilitou-lhe uma religiosidade pluriforme. Zigmunt Bauman defende a tese de que há uma nova modernidade chamada "modernidade fluída", caracterizada pela existência de uma mão invisível que desarticulou a sociedade pela ausência de padrões e referências. Tal fato provocou mudanças na condição humana, o que exige repensar os velhos conceitos que permeavam nossas análises. Este trabalho objetiva discutir que tanto no caso da Religiosidade em Pessoa, quanto no contexto atual, não é o desinteresse religioso que caracteriza nossa sociedade, é sim, a configuração de uma crença que escapa às grandes religiões. Para tanto, nesta pesquisa, partimos da literatura pessoana e olhamos a diversificação da própria crença religiosa.

Palavras-chave: Fernando Pessoa, Religiosidade, Epistemologia, Sociologia da Religião

\section{Abstract}

Fernando Pessoa (1888-1935) was a pretender, he warned. His understanding of religion went 
beyond the established social boundaries. The use of heteronomy which has allowed him a multifaceted religiosity. Zigmunt Bauman advocates the thesis that there is a new modernity called "fluid modernity" characterized by the existence of an invisible hand that the company dismantled by a lack of standards and benchmarks. This fact changed the human condition, which requires rethinking the old concepts that permeated our analysis. This paper discusses that both in the case of Religiosity in person, as in the present context, is not religious indifference that characterizes our society, yes, the configuration of a belief that falls outside the major religions. To do so, in this research, we start from literature Pessoa and look to diversify their own religious beliefs.

Keywords: Fernando Pessoa, Religion, Epistemology, Sociology of Religion

O estudo ao meu respeito, peca só por se basear, como verdadeiros, em dados que são falsos por eu, artisticamente, não saber senão mentir.

Fernando Pessoa

\section{A poesia pessoana à guisa de uma introdução}

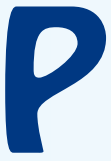

ouco antes de sua morte, em 30 de Novembro de 1935, no Hospital São Luís em Lisboa, vítima de cirrose provocada por ingestão de bebida alco-

ólica em excesso, Fernando Pessoa escreveu, em inglês, num fragmento de papel suas últimas palavras: "I Know not what tomorrow will bring" ${ }^{1}$. O sentido e a circunstância dessa frase remetem a uma de suas obsessões cognitivas: a existência. Este pendor especulativo levou-o a interessar-se pela religião.

Richard Zenith (2006b) apontou que "A temática acerca de Deus, ou dos deuses, e da nossa relação com eles" (Id., p. 5) foi a temática que mais inspirou Fernando Pessoa. Além dele, Cleonice Berardinelli, aclamada como uma das principais estudiosa da obra de Fernando Pessoa, define-o como uma pessoa com "febre de além", e afirma que o "espírito religioso" do poeta é tema central da poesia pessoana. Testificamos isso ao longo da pesquisa.

Muitos críticos e a maioria dos leitores tendem a encarar os perfis indivi-

1. Eu não sei o que o amanhã trará. 
dualizados do poeta português como entidades autônomas. Um levantamento bibliográfico sobre Fernando Pessoa levará o pesquisador a constatar que os trabalhos acerca do poeta se constituem de teses, dissertações e monografias parciais, em torno de Campos, Caeiro, Reis ou A Mensagem e assim por diante. Esse fato pode decorrer da perda da visão em conjunto. Esta aproximação fragmentadora, que tende a isolar cada heterônimo num compartimento estanque, monolítico, abdica da sedução de considerar a heteronímia como um todo, regido por algum princípio caótico de ordem interna e não pela arbitrária justaposição de máscaras independentes.

O fato da heteronímia, semi-heteronímia e a ortonímia pessoana não constituírem compartimentos estanques evidencia-se na existência de múltiplas relações, vasos comunicantes entre as diferentes vozes do poeta, seja por via das afinidades ou pelos antagonismos. Assim, tomo este quadro como processo dinâmico e não estático. Somos, enquanto leitores, fortemente influenciados em nossa compreensão pelo critério ordenador das partes que constituem a poética pessoana ${ }^{2}$. O leitor é imperceptivelmente instado a considerar o ortônimo como ponto-chave, ou ponto de origem, do qual partem em posição secundária, os heterônimos, em desdobramentos sucessivos.

Entendo ser imprescindível reaver a relação e o diálogo entre a universalidade e as singularidades. A dialogia entre o uno e o múltiplo, uma das principais características do pensamento complexo, aparta-se incisivamente do "generalismo estéril das leis gerais", tanto quanto do "relativismo pueril que insulariza o singular" (Almeida, 1997). Assim, Fernando Pessoa não é apenas um poeta do qual se desdobram outros, ou, simplesmente a coexistência em si mesmo de outros seres.

Ao meu ver isto não é apenas um problema interpretativo, teórico. Muito

2. Jacinto Prado Coelho considera Fernando Pessoa como sendo o "eu profundo" e os heterônimos, "os outros eus". Em determinado momento, o crítico português afirma: "não obstante os estilos dos heterônimos traduzirem atitudes temperamentais e modos de conceber a vida diferentes, é possível (...) reduzir as afinidades de estilo dos heterônimos a uma unidade psíquica basilar" cf. PESSOA, Fernando. Páginas íntimas e de auto-interpretação, p. 140. Esta análise exerceu e exerce grande influência, Afrânio Coutinho publicou em 1980 uma seleção com poemas de Pessoa. E intitulou a coletânea de "O Eu profundo e os outros Eus". 
mais, trata-se de uma crise paradigmática, ancorada na crise de pensamento a qual estamos atravessando. Este trabalho, como alguns outros, se fez pela necessidade de se reorganizar o conhecimento, dada a insuficiência das explicações científicas produto de uma cosmovisão simplificadora, redutora, fragmentada e fragmentária, que resulta numa interpretação da cultura endurecida e inadequada ao mundo contemporâneo.

Fernando Pessoa é poeta. Não se fecha ao restrito território dos jogos de palavra e dos símbolos. Como poeta, possui competência, complexa, multidimensional que concerne à humanidade e à religião. Sua mensagem religiosa implica ultrapassar os limites instituídos socialmente para o religioso, não se submetendo a organizações e ou instituições religiosa. Nossos viciados esquemas interpretativos têm reduzido e, sucessivamente fragmentado, as análises de sua poesia. A questão religiosa dentro da obra pessoana tem sido pouco discutida. E, quando feita, muitos dos comentadores desconsideram a possibilidade de uma expressão religiosa plural, multidimensional. O poeta português é sempre reduzido numa expressão religiosa única, seja ela, o catolicismo, esoterismo, ceticismo, a maçonaria ou qualquer outra, mas sempre recebendo um tratamento monolítico, unilateral.

Entre os estudiosos que marginalmente trataram da questão religiosa em Fernando Pessoa, e que o fizeram de maneira monocular posso destacar Nogueira (2003) e sua ênfase ao Pessoa budista; Costa (1978) que publicou um trabalho evidenciando o Fernando Pessoa esotérico; Azevedo (1972) que considera o poeta português um teósofo; Papus (1976) destacou os aspectos relacionados ao Espiritismo; Perrone-Moisés (1982) que trabalha os aspectos que o aproxima da filosofia oriental; Sandra Abdo (2002), vê Pessoa como um cético; O psicanalista Gilberto Safra (2005) ao analisar o poeta português afirma: "A religiosidade de Fernando Pessoa se limita aos deuses pagãos"; Ordoñez (1994) que concebe o poeta com sendo um "Místico sem fé", cético por ser excessivamente racionalista; Moisés (2005) que vê em Pessoa um católico inconformado, um místico sebastianista; Mesquita (1996) é categórico em afirmar o pertencimento do poeta português a ordem ocultista. Além de coletâneas publicadas com textos maçônicos de Fernando Pessoa, e outras aproximações. Não me 
alongarei aqui nos exemplos, retomo muitos deles ao longo do trabalho no qual me proponho. A leitura que tais estudiosos fizeram de Fernando Pessoa não é equivocada, apenas reduz a possibilidade de uma religiosidade multifacetada.

O caráter transgressivo do sujeito na literatura, neste caso na poesia, possibilita pensar o quanto é possível transgredir na vida. Ao debruçar sobre a capacidade pessoana de desdobrar-se em vários indivíduos e através destes exteriorizar diferentes formas de ver o mundo, isto é, diferentes expressões religiosas, mostro ou sugiro a possibilidade de fugir da compartimentalização religiosa existente, vigente e coercitiva, fruto de um pensamento ancorado num paradig$\mathrm{ma}^{3}$ moderno, que ainda age em nossos dias.

Um todo organizado produz qualidades e propriedades que não existem nas partes tomadas isoladamente. Portanto, é necessário ter um pensamento que possa conceber o todo e as partes simultaneamente, o sistema e a organização, pois tudo que conhecemos é constituído da organização de elementos diferentes.

Espero que tenha ficado evidente que não tentarei explicar (isto é, interpretar) absolutamente nada. Este, se trafegássemos por ele, seria um caminho traiçoeiro. Explicar vem do latim ex-plicare, um verbo que por sua vez deriva de plicare, que significa dobrar. Explicar é, assim, tirar as dobras. Alisar o texto, como um ferro que alisa o pano, de forma a eliminar todas as dobras e por conseguinte eliminar todas as sombras.

Durante parte de sua vida, entre 1942 e 1948, Bachelard acreditou que a imaginação dos elementos - água, ar, terra, fogo - poderia explicar as imagens poéticas objetivamente, isso o motivou a escrever quatro livros desenvolvendo esta temática; $A$ água e os sonhos; $O$ ar e os sonhos; $A$ terra e os devaneios da vontade e A terra e os devaneios do repouso. Ao produzir $A$ poética do espaço (1957) deu, nos seus próprios termos, uma guinada fenomenológica e chega a conclusão que não era possível levar adiante seu empreendimento, visto que a poesia está sob outro signo, o da anima. A partir de então, ele passa a fazer a

3. Compreendo que paradigmas são estruturas de pensamento que de modo inconsciente comandam nosso discurso. 
defesa da fenomenologia da imaginação ${ }^{4}$.

A imagem poética, para o mesmo Bachelard, não necessita de nenhum conhecimento. Isso porque ela não é eco do passado, e sim, o inverso: "Pela explosão de uma imagem, o passado longínquo ressoa em ecos..."

Interessa-me, repito, a poesia de Pessoa. E, neste sentido Gaston Bachelard lembra que racionalizar a literatura não é função da atividade literária. Sua finalidade seria maravilhar-nos, fazendo-nos viver grandes imagens. Deste modo, uma crítica autêntica é uma aventura do conhecimento, a ciência começa muito mais com um devaneio do que com a experiência. Só se pode pesquisar aquilo que já foi sonhado.

\section{Fernando, mais um personagem do Pessoa?}

Ao discutir sobre a falta de provas acerca da vida desse cidadão português, Antônio Tabucchi, um dos mais lúcidos estudiosos do poeta, sugere a possibilidade de que Pessoa nunca tenha existido, e que tenha sido invenção de um tal Fernando Pessoa, um seu homônimo alter ego em meio a um turbilhão alucinante de personagens que, como Fernando, partilharam as "modestas pensões lisboetas onde ele, durante trinta anos, arrastou o ramerrão da mais banal, da mais exemplar vida de um mangas-de-alpaca." (grifos do autor).

A hipótese de que Fernando Pessoa fosse alter ego de um Fernando Pessoa completamente igual ao primeiro é verdadeiramente alucinante e talvez, absurdamente, a mais óbvia. O próprio Pessoa já em 1931 nos forneceu o paradoxo sobre o qual se assenta minha - e não somente minha - suspeita. Ei-la:

O poeta é um fingidor

finge tão completamente que chega a fingir que é dor a dor que deveras sente.

Assim, resta-nos imergir nos "dados" biobliográficos daquele que foi a fic-

4. cf. SIMÕES, 2003.

5. Bachelard, G. O direito de sonhar, xxvi.

6. TABUCCHI, A. Pessoana mínima, p. 11. 
ção de um impostor idêntico a si próprio, ou seja, Fernando Antônio Nogueira Pessoa.

Em 1935, no último ano da sua vida, o poeta confessa-se em nota biográfica "cristão gnóstico". Ele foi batizado e educado, enquanto criança, dentro dos parâmetros da religião católica. Existe um documento dele, datado de 1907, dirigido ao pároco da freguesia em que fora batizado ${ }^{7}$. Compreendo que Pessoa definia gnose, termo gerador do adjetivo por ele empregado gnóstico, como o conhecimento esotérico perfeito da divindade, que se transmite por meio da tradição e mediante rituais de iniciação.

Em 1934, em plena vigência do regime salazarista, foi instituído o prêmio literário "Antero de Quental", a ser atribuído ao melhor livro de poesia nacionalista que se submetesse neste concurso. Por insistência de amigos, especialmente o Sá-Carneiro, Pessoa publicara no mesmo ano seu primeiro (e único em vida) livro em língua portuguesa, a Mensagem. O resultado, divulgado em 31 de dezembro de 1934, atribuiu o prêmio ao livro Romaria, do padre franciscano Vasco Reis. Alegando ver nele "uma obra de genuíno lirismo português, que revela uma alta sensibilidade de artista e que tem um sabor marcadamente cristão e popular"8 Para Mensagem foi criado um prêmio de "segunda categoria" na tentativa de atenuar a falta, tendo em vista que esse tipo de premiação não era prevista nos regulamentos.

Até pouco antes de ser publicado o livro chamava-se Portugal. Nos últimos instantes, o título foi substituído, "por não achar a sua obra à altura do nome da Pátria" e por Mensagem "estar mais dentro da índole do trabalho e, ainda, por ter o mesmo número de letras"9.

Mensagem se distingue das epopéias conhecidas, seu foco de interesse é o futuro e não o passado. A fonte propulsora do poema de fato remetem para a história de Portugal, como Os lusíadas - ou tal como a Eneida, para a história de Roma. Mas, contrariamente a Camões e Vergílio, que enchem de glória o

7. Neste documento, Pessoa contesta o fato de ter sido batizado quanto ainda era "ente irracional".

8. Nota divulgada pelo Diário de Lisboa em 4 de Janeiro de 1935.

9. SIMÕES, J. G.. Vida e obra de Fernando Pessoa, p. 317. 
passado e, em meio a esta exaltação, chamam atenção para as dificuldades do presente, Pessoa lança seu olhar em algo que estar por vir. Os acontecimentos do passado são sinais misteriosos que necessitam ser desvendados e assim entrever o futuro. O tema da história do futuro foi recorrente na cultura portuguesa. De modo é possível dizer que é sob este terreno fértil que Pessoa cultiva sua doutrina messiânica, expresso em seu Quinto Império.

Neste ponto penso ser necessário um esclarecimento. Há uma diferença entre a concepção linear da história, sem repetições e a compreensão cíclica da história. Nessa última, há uma mudança de contornos, cenários, mas a história sempre é essencialmente a mesma. E, é esta compreensão que possibilita a percepção dos fatos que ainda acontecerão, se o sujeito se atentar ao presente, aos sinais que hoje se apresentam. Assim, é possível falar em história do passado.

Tratar de messianismo, em matéria de cultura portuguesa, é falar do mito de Dom Sebastião. Para tanto, outros aspectos devem ser trazidos à tona. Entre 1530 e 1540, Gonçalo Annes, um sapateiro simples do povoado de Trancoso, bem mais conhecido na história de literatura portuguesa como "Bandarra", representante da "cultura artesã apocalíptica" ${ }^{10}$, é o elemento responsável pela transição e transmissão na esfera popular do messianismo, transitando entre cristãos novos e velhos ${ }^{11}$. O ilustre sapateiro assimila diversos elementos de ambas culturas para redigir suas trovas, ao fazê-lo também cumpre o papel de intermediador entre o oral e o escrito, o que antes era cultura oral passa a existir na forma escrita, ou seja, Bandarra é o grande mediador entre dois mundos: o cristão novo e o cristão velho; o oral e o escrito; o popular e o erudito ${ }^{12}$. As trovas de Bandarra tem três eixos temáticos: a sociedade e a hierarquia quebrada; a esperança de um novo mundo e a atribuição a um rei português a missão salvadora ${ }^{13}$ e é esse texto que circula entre o povo que tem o sapateiro como "profeta".

10. HERMANN, J. No reino do desejado: a construção do sebastianismo em Portugal (séculos XVI e XVII), p. 49; 121.

11. Idem, p. 46.

12. Idem, p. 41.

13. MEGIANNI, A. O jovem encantado: aspectos da construção e personificação do mito messiânico português, p. 30-31. 
Anos mais tarde, em 1578, desaparece o jovem rei D. Sebastião numa bataIha contra os árabes no norte da África. Com seu rei morto e sem descendentes,o reino de Portugal foi anexado a Castela, seu ávido rival. O fato de nunca ter sido encontrado o corpo do rei associado à sujeição a Castela, fundido às coplas de Bandarra deu origem, ao mito português por antonomásia: o regresso de D. Sebastião traria consigo o ressurgimento de Portugal.

Esta crença prosseguiu com o passar dos séculos e durante a segunda metade do século XVII dá-se sua metamorfose mais importante, quando o padre jesuíta Antônio Vieira profetiza a instauração do Reino de Deus sobre a Terra, que ele chamou de "Quinto Império", um reino de mil anos que abarcaria todas as raças e todas as culturas. ${ }^{14}$

Na medida em que se configura este quadro, é importante mencionar Joseph Campbell. Para ele, os mitos "são temas que deram sustentação à vida humana, constituíram civilizações e enformaram religiões"15. Os mitos - manifestações da alma humana, e, por isso, identificáveis em todas as culturas - são "sonhos arquétipos" da humanidade, e afloram independente do nível de isolamento dos grupos. Alguns fatores responsáveis pela estruturação dos mitos são identificáveis, neste caso o que parece ser mais significativo é o sofrimento. É no sofrimento que a criatura humana busca alternativas, "é que no fundo do abismo, desponta a voz da salvação. O momento crucial é aquele em que a verdadeira mensagem de transformação está prestes a surgir. No momento mais sombrio surge a luz."16.

Dentre aqueles que contribuem para a compreensão do mito está LéviStrauss e a sua constatação de que cada grupo social expressa suas construções míticas, suas atitudes em relação ao mundo e suas maneiras encontradas de resolver os problemas da existência. Sua assertiva é que o mito não se sujeita a "nenhuma regra de lógica ou de continuidade"17, e é considerado como tal enquanto for assim percebido e reconhecido.

14. Cf. Vieira, A. Livro anteprimeiro da história do futuro.

15. Cf. O poder do mito, p. 4.

16. Idem, p. 39.

17. Cf. Antropologia Estrutural, p. 239. 
A idéia de Quinto Império, advogada em Mensagem por Pessoa (1998), se origina diretamente do Sebastianismo e das profecias bíblicas, especialmente do livro de Daniel. O sonho de um Quinto Império português, promessa antiga do sapateiro Bandarra, reforçada pelo Pe. Antônio Vieira e realimentada ao longo dos séculos, se manifesta invariavelmente nos momentos históricos em que é forte a sensação de crise e decadência. Situação que remete a confiança no futuro da nação: "glória" e "desgraça" indissociavelmente irmanadas, como pode ser percebido no poema $O$ das quinas:

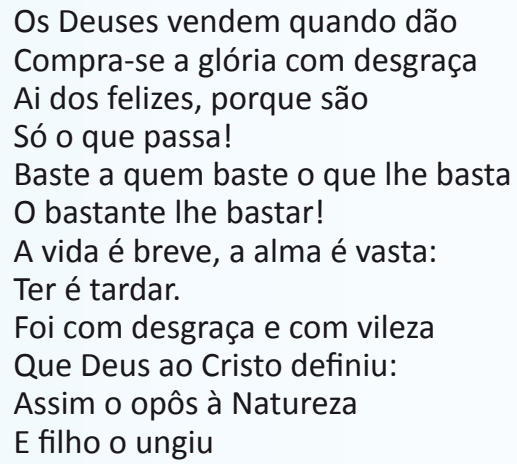

Tanto no judaísmo como no cristianismo, divisões do mesmo tronco teológico e religiões predominantes em Portugal, são crenças predispostas ao milenarismo (mais comum na concepção linear da história) e ao messianismo (história cíclica). Para ambos ${ }^{18}$ :

o mito escatológico (...) se diferencia dos demais pela pregação de uma purificação e não de uma nova concepção, e este paraíso devolvido não terá mais fim. O tempo circular da eterna destruição/reconstrução dá lugar ao tempo linear sem repetições. Além do mais insere-se o componente messiânico articulado com o fim do mundo e a chegada do paraíso.

A imagem poética da profecia do Quinto Império, da qual me refiro, pode ser vista com maior nitidez nas duas últimas estrofes do poema intitulado, não por acaso, Quinto Império:

18. ELIADE, M. O sagrado e o profano, p. 62. 


\begin{abstract}
E assim, passados os quatro
Tempos do ser que sonhou,

A terra será teatro

Do dia claro, que no atro

Da era noite começou.

Grécia, Roma, Cristandade, Europa - os quatro se vão

Para onde vai toda idade

Quem vem viver a verdade

Que morreu d. Sebastião?
\end{abstract}

No livro de Daniel, as profecias dão conta de quatro grandes impérios, Babilônia, Pérsia, Grécia e Roma. Pessoa associa-os ao Sebastianismo, com outro corte temporal, desconsidera os dois primeiros e acrescenta Cristandade e Europa. A estes, seguir-se-ia o Quinto Império, quando D. Sebastião regressasse para governá-lo como reencarnação de Cristo. No livro do profeta Daniel, assim está dito acerca dos últimos dos impérios (ou tempos) da humanidade ${ }^{19}$ :

E depois se realizará o juízo, a fim de que lhe seja tirado o poder, e ele seja destruído e pereça para sempre, e seja dado o reino, o poder e a grandeza do reino, que está debaixo de todo o céu, ao povo dos santos do Altíssimo, cujo reino é um reino eterno, e ao qual servirão e obedecerão todos os reis.

Portanto, Pessoa parte da percepção que a "Cristandade" rompeu com o mundo antigo, embora se originasse dele. Iniciava-se desse modo, uma civilização exclusivamente cristã, esse monopólio religioso foi o desvio responsável pelo desvirtuamento do autêntico cristianismo. O Quinto Império recolocaria as coisas no devido lugar.

A imagem do mar é algo extremamente forte na cultura portuguesa, e não poderia deixar de sê-lo na obra de Fernando Pessoa. A este aspecto ele dedica a segunda parte do livro Mensagem, e a intitula de Mar Português. As imagens aquáticas evocam a totalidade das virtualidades, matriz de todas as possibilidades de existência. De acordo com Eliade as águas simbolizam a substância primordial de que nasce todas as formas, e para qual voltam, seja por regressão ou por cataclismo. Nos versos de Pessoa "a terra inteira, de repente" surge do

19. Livro de Daniel, 7-26,27. 
"azul profundo". Eliade vai adiante ${ }^{20}$ :

Na cosmogonia, no mito, no ritual, na iconografia, as águas desempenham a mesma função, qualquer que seja a estrutura dos conjuntos culturais nos quais se encontram: elas pertencem qualquer forma e suportam qualquer criação. A imersão na água simboliza o regresso pré-formal, a regeneração total, um novo nascimento.

Outros aspectos desse livro pessoano, relativos à sua estrutura formal quanto ao sentido obscuro de alguns poemas, guardam afinidades com ensinamentos rosacrucianos. A Rosacruz é constituída de um sistema extremamente organizado que, em geral busca uma "explicação científica" para seus conceitos metafísicos. Seu embasamento dogmático é sutilmente balizado por princípios básicos da teologia cristã. Isto a torna bastante próxima da Teosofia. Ambas pertencem a uma mesma corrente do Ocultismo.

No poema $O$ encoberto temos impresso, entre outros simbolismos, os principais emblemas da Rosacruz, a "cruz" e a "rosa". Neste plano, é representado a figura de Cristo, que derrama seu sangue na cruz, objetivando que a "rosa do coração", adormecida na alma-núcleo, volte à tona. Assim, em Mensagem, o poema $O$ encoberto lida com esses temas. A cruz representa o corpo e a rosa o espírito. Eis o poema:

Que símbolo fecundo

Vem na aurora ansiosa?

$\mathrm{Na}$ Cruz Morta do Mundo

A Vida, que é a rosa.

Que símbolo divino

Traz o dia já visto?

$\mathrm{Na}$ cruz, que é o Destino

A Rosa que é o Cristo.

Que símbolo final

Mostra o sol já desperto?

$\mathrm{Na}$ Cruz morta e fatal

A Rosa do Encoberto.

20. Ibidem, O sagrado e o profano, p.153 
Em sua forma, a poesia é composta de três estrofes de quatro versos. Não obstante, no rosacrusismo o número três remete ao divino e quatro é o número da terra ou da matéria.

É consensual entre os críticos de Pessoa $^{21}$ que a divisão tripartida da Mensagem sugere uma interpretação da história de Portugal em três fases: ascensão, apogeu, declínio. Se nos valermos do universo explicativo pertencente à tradição rosacruciana, poderemos pensar nessa divisão como instantes-chave de um relato mágico-cosmogônico, nesse sentido a história portuguesa seria indícios externos, metáfora.

O interesse de Pessoa pelo ocultismo é algo recorrente nos estudos ao seu respeito. André Mesquita considera essa faceta a única evidente na obra do poeta, e ousa afirmar: "sua obra guarda os principais conceitos do ocultismo da nossa época e é leitura fundamental para quem se interessa pelo assunto"22.

O ocultismo - estudo pelo qual o homem através dos tempos busca vasculhar os labirintos da sua mente, visando fundamentalmente o auto-conhecimento, o controle do universo que o cerca e a sua própria iluminação - foi tema de uma carta escrita pelo poeta e endereçada a Adolfo Casais Monteiro, em 14 de Janeiro de 1935. Cito-a:

Falta responder a sua pergunta quanto ao Ocultismo. Pergunta-me se creio em Ocultismo. Feita assim, a pergunta não é bem clara; compreendo porém a intenção e a ela respondo. Creio na existência de mundos superiores ao nosso e de habitantes desses mundos, em experiências de diversos graus de espiritualidade sutilizando-se até chegar a um Ente Supremo, que presumidamente criou este mundo. Pode ser que haja outros Entes, igualmente superiores hajam criado outros universos, e que estes universos coexistam com o nosso, interpenetrantes ou não.

Nesta mesma carta Fernando Pessoa nega pertencer a qualquer ordem e pede que ela não seja publicada. Tal pedido faz com que alguns, como o próprio André Mesquita, argumentem em favor do seu pertencimento a alguma ordem

21. Cf. MOISÉS, C. Fernando Pessoa: almoxarifado de mitos, 2005.

22. MESQUITA, A. Fernando Pessoa: o ocultismo na ótica poética, p. 55. 
ocultista e estava mantendo seu voto de silêncio. Se ele foi ou não um iniciado, nunca saberemos. Mas, salta aos olhos imagens poéticas relacionadas a esta esfera religiosa.

Não podemos desprezar, por qualquer que seja o motivo, o comprometimento do poeta e da sua obra, com as raízes mágicas do ocultismo. Isso, sem desconsiderar o fato de ser a própria magia aliada e cúmplice da inspiração poética. Mallarmé atribuía ao poeta a missão de encontrar uma visão órfica da terra. E, a própria designação latina vate refere-se àquele que nomeia as coisas, que tem poder sobre elas, isto é, vidente, profeta.

Sabe-se, também, que Fernando Pessoa foi um excelente astrólogo. Ele chegou a elaborar o mapa astral de cada um dos heterônimos ${ }^{23}$ e foi exatamente por esse tipo de conhecimento que ele dispunha que foi possível travar contato com Aleister Crowley, famoso ou como distinguem os ingleses, notável mago.

Enquanto "A besta 666"24 corria o mundo provocando escândalos, o poeta português, na pacata Lisboa, fazia suas viagens internas. Em suas leituras deparou-se com a autobiografia de Aleister Crowley e nela percebeu que o horóscopo que Crowley traçara para si mesmo estava equivocada. Imediatamente tomou uma folha de papel e escreveu para o mago, apontando o erro astrológico. A carta, endereçada à editora, chegou às mãos do autor. Este reconheceu o erro e respondeu. Impressionado decidiu visitar o poeta em Lisboa para conhecê-lo. Pessoa, avesso à notoriedade, não gostou da idéia de acolher o mago. Este foi mesmo assim.

Um fato decisivo e introdutor de Fernando Pessoa no estudo das disciplinas teosóficas e ocultistas foi a tradução para o português que, a pedido da editora Livraria Clássica de Lisboa, ele fez dos livros de Annie Besant, sucessora de Helena Petrovna Blavatsky à frente da sociedade teosófica ${ }^{25}$.

23. Além do mapa astral de cada heterônimo, Pessoa elaborou também a assinatura de cada um deles.

24. A besta 666 foi um nome adotado por Aleister Crowley.

25. A sociedade teosófica foi fundada em 1895, na cidade de New York. 
Em carta dirigida à sua tia Anica, datada em 24 de junho de 1916, Fernando Pessoa confessa sentir-se com características de mediunidade, desenvolve práticas de espiritismo reveladoras, juntamente com seu interesse pela teosofia, pelos Rosa-Cruzes, seu gosto e prática da numerologia e astrologia, e ainda o seu "pendor para o oculto". Ainda nesta carta o poeta acrescentou que via a "aura magnética" das pessoas e que quando seu amigo Mário de Sá-Carneiro estava na crise que o levaria ao suicídio, fora acometido de uma "súbita depressão vinda do exterior" que não conseguira explicar ${ }^{26}$.

Enquanto residiu na casa de sua tia Ana Luísa Nogueira de Freitas o poeta presenciou várias sessões espíritas ${ }^{27}$. E isto parece ter marcado profundamente o imaginário poético dele. Um dos seus mais conhecidos poemas, por mim já mencionado, se chama Autopsicografia. Este título é decomponível em dois termos. Como o primeiro deles não oferece dúvidas, detenho-me no segundo. Em seu contexto de origem, o Espiritismo, este sentido de "psicografia" envolve uma dualidade: $\mathrm{o}$ ato de psicografar envolve um agente voluntário (o espírito), que seria o verdadeiro autor do texto a ser psicografado, e um agente involuntário (o médium), mero instrumento de que o primeiro se serve. O primeiro está num plano invisível, imaterial, inacessível e o segundo situa-se num plano material e tangível, acessível a qualquer um de nós. Para o espírito, o conteúdo psicografado é apenas uma potência, que só se atualiza por intervenção mediúnica.

De acordo com as doutrinas espíritas, o espírito e o médium são entidades rigorosamente distintas. O segundo é um espaço ocasional através do qual, e/ ou em qual, o primeiro se manifesta. No poema pessoano, entretanto, o prefixo "auto", presente no título, remete para a possibilidade de espírito e médium serem uma só e a mesma entidade. Ele é espírito e médium de si mesmo.

Em 1935, em matéria publicada inicialmente no Diário de Lisboa, e mais recentemente disponível no livro As origens e a Essência da Maçonaria, Fernando Pessoa (2006c) comenta longamente, um projeto de lei proposto pelo Deputado José Cabral. Este projeto dispunha sobre "organizações secretas" e estabelecia

26. Para uma ampliação deste fato sugiro consultar Ibidem, SIMÕES, Vida e obra de Fernando Pessoa, pp. 585 - 587.

27. ORDOÑEZ, A. Fernando Pessoa, um místico sem fé, p. 68. 
fortes sanções para todos que pertencesse a essas organizações, que em caso específico objetivava inibir a maçonaria. No mesmo artigo, Pessoa demonstra com perspicácia o desconhecimento do deputado do tema, ao contrário dele, que "sabe o que está escrevendo", e talvez mais que isso "Tendo eu, porém, certa preparação, cuja natureza me não proponho a indicar"28.

\section{As outras Pessoas do Pessoa}

Até aqui penso ter demonstrado a multiplicidade das expressões religiosas presentes em Fernando Pessoa (ipse). Desde sua Prece, expressão do seu sentimento religioso cristão, monoteísta; passando por expressões ocultistas, sejam, astrologia, teosofia ou rosacrusismo e sua imersão na escrita automática (autopsicográfica), própria do Espiritismo e sua adesão à Maçonaria

Mas, o Pessoa não se faz apenas de uma pessoa. Sobre este trilho que convido a seguir comigo pelas próximas linhas.

\subsection{Alberto Caeiro}

Caeiro, híbris da produção poética de outros heterônimos, nasceu em abril de 1889 , em Lisboa. Além de $O$ Guardador de Rebanhos, deixou o diário poético intitulado $O$ pastor amoroso e várias poesias dispersas, que Fernando Pessoa recebeu de Álvaro Campos e, posteriormente, haveria de reunir com o título Poemas Inconjuntos. Quem prefaciou o livro de Caeiro, foi ninguém menos que Ricardo Reis que comenta ${ }^{29}$ :

Os parentes de Alberto Caeiro, a quem ele deixou entregue o seu livro completo, e os poemas dispersos que o suplementariam, quiseram que eu, única pessoa a quem o destino concedeu que pudesse considerar-se discípulo do poeta, fizesse uma espécie de apresentação, ou de prefácio explicativo, à coleção de seus poemas.

A poesia de Caeiro despreza a mediação operada pelos signos e aspira uma

28. PESSOA, F. As origens e essência da Maçonaria, p. 50.

29. PESSOA, F. Mensagem, p. 111 
utopia da realidade. Seu desejo é um mundo em que os processos de significação não sejam mais necessários. Esse entendimento é necessário para a compreensão da estética do mestre dos heterônimos ${ }^{30}$, mais o será na percepção da concepção religiosa que permeia essa persona.

O "Mestre" gostaria de crer, mas sua honestidade para com as suas emoções e o pensamento não the permitem "Quando os relâmpagos sacudiam o ar [...] Pus-me a rezar a Santa Bárbara Como se eu fosse a velha tia de alguém. [...] Sentia-me alguém que possa acreditar em Santa Bárbara.... Ah, poder crer em Santa Bárbara!"31. Talvez por isso não acreditasse em Deus, nunca tinha o visto, e afirma: "Não acredito em Deus porque nunca o vi. Se ele quisesse que eu acreditasse nele, Sem dúvida que viria falar comigo E entraria pela minha porta dentro Dizendo-me, Aqui estou!"32. Assim compreende que Deus não é possível, ao ser possível deixa de ser Deus.

Alberto Caeiro concebe uma poesia existencialista. Não o existencialismo urbano, esta dimensão poética se faz presente em Álvaro Campos. Mas um existencialismo de feição campestre, que desconfia da metafísica, da teoria, das palavras, com a serenidade e o sossego de quem não duvida. Seu materialismo inocente ensina a difícil aprendizagem do desaprender, repulsa (e na medida que o faz, atrai) o transcendentalismo. É anti-filósofo e anti-metafísico ${ }^{33}$.

Neste sentido, o existencialismo de Caeiro tem uma feição notadamente budista. $\mathrm{O}$ budismo tem muito de materialismo, como também de niilismo. $\mathrm{E}$ nisto Lucila Nogueira, estudiosa pessoana, concorda comigo ${ }^{34}$.

Epicuro foi igualmente niilista. O próprio ideal budista do nirvana tem muito a ver com a catarse grega. De modo que tanto o budismo como o epicurismo e o existencialismo tentam libertar o espírito das perturbações que o afligem. A felicidade do epicurista é uma felicidade de aniquilamento, ou, para usar a

30. Para um aprofundamento nesse aspecto, sugiro GAMA, Rinaldo. O guardador de Signos: Caeiro em Pessoa, 1985.

31. PESSOA, F. [Caeiro]. Ficções do interlúdio/1: Poemas completos de Alberto Caeiro, p. 37.

32. Idem, p. 40

33. Cf. ANTUNES, A. Saudade e Profetismo em Fernando Pessoa, p. 351.

34. Cf. NOGUEIRA, L. A lenda de Fernando Pessoa, 2003. 
expressão do universo simbólico budista, uma felicidade de nirvana.

O epicurismo é uma ascese que se estabelece sobre uma visão materialista do mundo. Ele significou na Grécia, o ocaso do pensamento aristotélico. E, a adesão do mundo ocidental contemporâneo ao budismo, assim como a adesão intelectual ao existencialismo representam a falência dos postulados de uma forma da razão.

Tanto quanto Fernando Pessoa (ipse), e as outras personae pessoanas, Caeiro está em busca da verdade. Só que, do seu ponto de vista, essa busca não consiste em desvelar as razões que se escondem por trás das aparências, e sim, antes, em deter-se nas aparências.

No VIII poema de $O$ Guardador de Rebanhos conta-se a descida do menino Jesus à terra, com sabor de história infantil, e desmonta inocentemente o quebra-cabeças da Trindade, desanuvia o martírio da crucificação e com riso de uma eterna criança encontra "O Deus que faltava", humano e natural. Uma ousada descrição cristológica. Um Deus-menino. Travessura e alegria compõe tal quadro.

Em Caeiro nota-se sua percepção pagã do mundo e a aproximação da sua poesia com elementos do budismo. Cabe, entretanto, destacar que as imagens suscitadas a partir do VIII poema do guardador de rebanhos pode demonstrar sua descrença em relação a prática religiosa institucional, mas também o seu apego a uma espiritualidade sustentada por uma leveza oriunda do contato com o belo.

\subsection{Ricardo Reis}

Ricardo Reis viveu em terras brasileiras até a sua morte, em 30 de novembro de 1935. Nascera em Lisboa ${ }^{35}$ em 19 de setembro de 1887, às 16 horas e 05 minutos e fora educado num colégio de jesuítas. Segundo Fernando Pessoa, foi

35. Em carta a Adolfo Casais Monteiro, datada de 13 de janeiro de 1935, Pessoa altera o local do nascimento de Ricardo Reis para o Porto. Lisboa fora o local escolhido anteriormente no mapa astral do médico. 
"um latinista por educação alheia e um semi-helenista por educação própria"36. Apesar de ser médico não se serviu, pelo menos que conste, da sua profissão para sobreviver.

Apesar da invocação e exaltação de Epícuro como modelo e patrono espiritual de sua busca do fim supremo da ataraxia, Reis não adere - semelhante as outras personas do Pessoa - irrestritamente aos seus ensinamentos. E, na medida que se distancia de tais ensinos aproxima-se de outra forma de espiritualidade. Um bom exemplo do que tenho dito são os versos que se seguem: "Lídia, a vida mais vil antes da morte,/ Que desconheço, quero"; "Temo Lídia, o destino. Nada é certo. / Em qualquer hora pode suceder-nos / o que nos tudo mude". O poeta confessa ter sido tomado pelo temor, tanto da morte quanto do poder dos deuses sobre o destino humano, contrariando assim, frontalmente as recomendações de uma das máximas epicuristas ${ }^{37}$ :

Habitua-te a pensar que a morte nada é para nós, visto que todo o mal e todo o bem encontram-se na sensibilidade: a morte é a privação da sensibilidade.

De fato constitui-se um engano pensar que a doutrina epicurista, ou qualquer outra, constitua para Reis uma direção unívoca. Neste a emoção comparece, mas inteiramente sujeita ao controle da razão, e voltada tão somente para articulação de idéias e questões que dizem respeito aos grandes temas (que também são objetos dos embates religiosos) e inquietações do homem: a existência, os deuses, o destino, a beleza, o sentido da vida, a virtude, o tempo, a arte, a dor, a alegria, a morte, o prazer, entre outros. Isto meticulosamente engendrado por reflexões filosóficas de caráter estóico-epicurista, num português erudito e latinado.

Pierre Hourcade chama atenção para as impecáveis odes horacianas, e as qualifica como "concentração da sabedoria pagã em comprimidos"38. Representante do paganismo, além de adepto do "pensamento alto", Reis apre-

36. PESSOA, F. Escritos autobiográficos, automáticos e de reflexão pessoal,2006b.

37. EPICURO, et. al. Antologia de textos, p. 21

38. HOURCADE, P. Temas da literatura portuguesa, p. 131 
goa a indiferença do homem diante do poder e do arbítrio dos deuses, diante do destino inelutável e da morte como termo definitivo de toda vida.

Na visão do "pagão inocente da decadência"39 o cristianismo - ou cristismo, termo que ele prefere - é o mal de todos os males. Isso porque o Cristianismo introduz o tempo mítico no tempo histórico, baralhando-os, com o seu Deus que é divino e humano ao mesmo tempo, e por obrigar a dimensão do sagrado a transitar pela consciência e o foro íntimo de cada indivíduo, fonte de todo subjetivismo e toda desagregação. Reis, evidentemente, não reverencia o epicurismo nem o carpe diem horaciano. Se Caeiro é dotado de uma falsa serenidade, Reis é um falso árcade: ele volta ao passado, mas com os olhos fixos no presente e assim faz seu diagnóstico, não negando a realidade contemporânea.

A extrema flexibilidade do ecletismo religioso e filosófico de Reis faz transparecer sua aceitação e o tratamento igualitário a todos os deuses, seitas e doutrinas, religiosas e metafísicas. Todos seriam igualmente verdadeiros. Não existe deformação dos deuses, como no seu mestre Caeiro. Os deuses são úteis, já que servem "... para conduzirmos entre os homens". São ao mesmo tempo reais e irreais - "São irreais porque não são realidades, mas são reais porque são abstrações concretizadas. Uma abstração concretizada passa a ser pragmaticamente real; uma abstração não concretizada não é real mesmo pragmaticamente" ${ }^{40}$.

Neste panteão particularíssimo, também o Cristo tem lugar, mas como um deus a mais, que junta-se aos já existentes, sem qualquer prioridade. Embora em conjunto persistam elementos de cunho esotérico.

\section{3. Álvaro de Campos}

Álvaro Campos nasceu em Tavira, no Algarve. Embora tenha se graduado em Engenharia Naval por Glasgow, nunca exerceu a profissão e viveu a maior parte da sua vida inativo em Lisboa. Entretanto, sê-lo fará significativa diferença em sua produção poética. Foi incentivado ao estudo por um tio sacerdote que

39. Expressão utilizada por Fernando Pessoa (ipse) para caracteriar Ricardo Reis. 40. PESSOA, F. [Reis]. Ficções do interlúdio / 2-3: Odes de Ricardo Reis; Para lém do outro Oceano de Coelho Pacheco, p. 148 
vivia em Beira, que Ihe ensinou o latim, posteriormente recebeu educação vulgar de Liceu e, em seguida, foi mandado para a Escócia.

A poesia de Campos carrega consigo, na ironia e no cinismo, um desespero existencial que chega a ser ontológico. Esse mergulho é chamado pelo já referido ensaísta Carlos Felipe Moisés de "obsessão retrospectiva". Na medida em que imerge-se em si mesmo. Campos volta principalmente ao passado, preterindo o presente e o futuro. $E$, este retorno sempre com uma visão negativa, imposta pela inevitável mudança ${ }^{41}$.

O que ele é difere substancialmente do foi, a ponto de já não reconhecer: é o homem transformado em estranho para si mesmo. Daí decorre a sensação desconfortável de estar carregando dentro de si não só um estranho, mas um estranho irrecuperável.

Em Tabacaria, poema que para alguns é chave para a compreensão de Álvaro de Campos, imerge algumas lembranças do poeta. Não daquilo que ele foi, mas do que aparentou ser, criando um conflito entre o Eu-individual e o Eu-social.

Na constatação da ausência de Deus e no vício de pensar estão as raízes mais profundas da inquietação pessoana, aqui em Campos, materializada na sensação tantas vezes reafirmada da sua irrealização. O poeta reconhece o seu fracasso: "falhei em tudo". E, como se quisesse reiterar, repete-o em três metáforas da impossibilidade total:

Serei sempre o que esperou que lhe abrissem a porta ao pé de uma parede sem porta, E cantou a cantiga do Infinito numa capoeira, E ouviu a voz de Deus num poço tapado.

A negatividade, dúvida, contingência estão presentes no fazer poético de Campos, ainda que não determine o motivo. De fato, a angústia, segundo os filósofos existencialistas (vêm-me a mente Kierkegaard, pela estima que Pessoa tinha por ele) não possui causa específica, não se vincula às contingências, mas

41. Ibidem, MOISÉS, Fernando Pessoa: almoxarifado de mitos, p. 111 
remete à própria situação do homem no mundo, continuamente projetado para o futuro e às voltas com as possibilidades, que tanto pode concretizar-se quanto redundar num total fracasso. Muitas imagens ao longo de todo o poema remetem a este aspecto.

Além do "Deus morto" anunciado por Nietzsche. Assim, para Álvaro de Campos, a religião estaria na dimensão do prazer e não no âmbito mutilador da dominação institucional. Isso se deve a compreensão prudente do mito que possuía e que lhe possibilita uma compreensão ampla de divindade.

\subsection{Alexander Seach}

Seu nome anglo-saxônico (enigmatístico) e o fato de manter contato com Pessoa por meio de cartas desde 1899, quando este freqüentava a High School de Durban, poderiam fazê-lo supor sul-africano, ou mesmo inglês. Entretanto, em uma ficha escrita Pessoa declara que Alexander Seach nasceu em Lisboa no dia 13 de junho de 1888.

Dele foram publicados até hoje alguns textos, em inglês. Sobressai um pacto com o satanás, presente no diário do Pessoa, datado em 02 de outubro de 1907, intitulado Pacto para a vida de Alexander Seach. Este regimento de vida pessoal, contém quatro assertivas, a terceira do seu pacto chama-me atenção, partilho-a: "Nunca esquecer de atacar a religião em nome da verdade, que a religião dificilmente pode ser substituída e que o pobre homem chora nas trevas"42. Ao final deste texto, assinou com um símbolo (associado ao satanismo) e com a insignia 666 .

\subsection{Antônio Mora}

Certa vez Pessoa, inquieto com seus tormentos internos, resolveu fazer uma visita a uma clínica psiquiátrica em Cascais. Lá encontrou Antônio Mora, filósofo, passeando no pátio do manicômio. Segundo a descrição do próprio Fernando Pessoa, em um manuscrito intitulado Na casa de Saúde de Cascais

42. Ibidem, Escritos autobiográficos, automáticos e de reflexão pessoal, p. 74. 
dado a conhecer por Jacinto Prado Coelho, Mora era alto, imponente, de olhar vivo e arrogante, de barba branca que estava vestido com uma toga à romana, recitando o início da lamentação de Prometeu da tragédia de Ésquilo. Pessoa pediu ao Dr. Gama, médico que o acompanhava, para ser apresentado a Antônio Mora.

Pessoa conheceu o filósofo nessas circunstâncias quando este já era idoso e portador de "psiconeurose intercorrente", contudo considerava que "a loucura era condição inventada pelos homens para segregar as pessoas que incomodam a sociedade" (Cf. Tabucchi, 1996). Ele pregava o retorno dos deuses, inclusive por ocasião da conversa com Pessoa entregou-lhe os manuscritos de um projeto de livro chamado $O$ regresso dos deuses. Em que expõe sua visão acerca da temática que desenvolvo neste trabalho. Ei-la ${ }^{43}$ :

Os deuses não morreram: o que morreu foi a nossa visão deles. Não se foram: deixamos de os ver. Ou fechamos os olhos, ou entre eles e nós uma névoa qualquer se entremeteu. Subsistem, vivem como viveram, com a mesma divindade e a mesma calma.

Para esta persona do Pessoa, a religião era uma questão estética e fora os gregos com sua visão excessivamente nítida que nos influenciara. Havíamos trocado o sentir pelo ver. Para o único heterônimo assumidamente filósofo, o ver de maneira lúcida prejudica o sentir. Seu desejo era que criássemos em nós "uma nova forma de olhar e de sentir" ${ }^{44}$. Tal atitude propiciaria o ensejado regresso dos deuses.

\subsection{Raphael Baldaya}

Autor de dois livros, Tratado da Negação e de alguns Princípios de Metafísica Esotérica. Nestes reivindica a autoridade de ser porta-voz de uma "verdadeira ciência". Era opositor da teosofia, compreendia-a como uma "democratização do hermetismo, a sua cristianização". Morava em Lisboa. A partir de uma carta de Pessoa a Mario de Sá-Carneiro datada em 1915 pode-se deduzir que Baldaya

43. PESSOA, F.[Mora]. O Banqueiro anarquista e outras prosas, p. 258.

44. Idem, p. 259 
relacionava-se com Pessoa pelo menos desde aquele ano. Tabucchi (1984) afirma que na arca, espólio com $27543^{45}$ papéis de Fernando Pessoa, foi encontrado um cartão de visita impresso, informando seu nome e sua profissão: Raphael Baldaya, Astrólogo.

\subsection{Bernardo Soares e/ou Vicente Guedes}

Bernardo, o "ajudante de guarda-livros" ${ }^{46}$, passou toda a sua medíocre vida de modesto empregado na cidade de Lisboa. Morava sozinho, num quarto alugado, na zona comercial da cidade baixa, entre Rossio e o Tejo, próximo às companhias de importação e exportação de tecidos, e trabalhava em uma delas como assistente contábil, localizada na Rua dos Douradores. Soares conheceu Fernando Pessoa numa pequena cantina chamada "Pessoa", no qual era cliente fixo, foi em meio às mesas desse estabelecimento comercial que contou-lhe seu projeto literário, seus sonhos e presenteou-Ihe o Livro do Desassossego, diário metafísico da mediocridade cotidiana.

Curioso o fato que entre os papéis inéditos de Pessoa foram encontrados fragmentos de um outro Livro do Desassossego dum certo Vicente Guedes, que Pessoa conhecera no mesmo restaurante. Se trata de uma persona distinta ou da mesma não temos como afirmar categoricamente. Entretanto, não é despropositado pensar - como já o fez Tabucchi (1984) - que Bernardo Soares tenha assentido com a publicação em revista, por Pessoa, de algumas páginas de seu diário com a condição de ser apresentado sob o pseudônimo de Vicente Guedes (obviamente, não podemos rejeitar o discurso contrário, isto é, um Vicente Guedes que tenha escolhido o pseudônimo Bernardo Soares).

Tentava estabelecer uma relação entre as concepções antropológicas e o ideal de perfeição em diferentes expressões religiosas. "O homem perfeito do pagão era a perfeição do homem que há; o homem perfeito do cristão a perfeição do homem que não há; o homem perfeito do budista a perfeição de não

45. Cf. PERRONE-MOISÉS, L. Introdução ao Desassossego In: PESSOA, F. Livro do Desassossego, p. 10.

46. Cf. PESSOA, F. Livro do Desassossego, 1986. 
haver o homem" ${ }^{\prime 4}$.

\title{
2.8. Barão de Teive
}

Álvaro Coelho de Athayde, o 20 Barão de Teive, convencido de sua superioridade decidiu isolar-se na Quinta da Macieira, uma propriedade pequena afastada do centro urbano de Lisboa. Escreveu A Educação do estóico. Em 12 de julho de 1920 suicidou-se. Antes confessou: "Atingi, creio, a plenitude do emprego da razão. E é por isso que me vou matar". Assim terminou o aristocrata.

No que tange a religião, externaliza sua incredulidade ${ }^{48}$ :

\begin{abstract}
Pertenço a uma geração - supondo que essa geração seja mais pessoas que eu - que perdeu por igual a fé nos deuses das religiões antigas e a fé nos deuses das irreligiões modernas. Não posso aceitar Jeová, nem a humanidade. Cristo e o progresso são para mim mitos do mesmo mundo. Não creio na Virgem Maria nem na eletricidade.
\end{abstract}

Entretanto, ele mesmo, sente a necessidade de crer em algo. E sente-se incomodado com isso, dizia o Barão de Teive: "O conflito que nos queima a alma (...) é o conflito entre a necessidade emotiva da crença e a impossibilidade intelectual de crer" ${ }^{\prime \prime}$.

\subsection{Frei Maurice}

Personagem literária só recentemente conhecida. É um frade especial para Pessoa. Ansiava ser bom e praticar o bem, mas vivia em conflito com a sua fé religiosa. Certa vez, num jantar familiar animado. Os presentes, todos cordiais entre si, partilham da companhia excessivamente fria e inquietante do "pobre Frei Maurice" 50 . Richard Zenith, um dos mais respeitados estudiosos de Pessoa assinala: “Frei Maurice, é ele [Pessoa] próprio, uma espécie de alter-ego

47. PESSOA, F. [Soares]. Aforismos e afins, p. 35.

48. Idem, PESSOA[Teive], p. 22.

49. Idem, p. 26

50. Cf. Ibidem, Escritos autobiográficos, automáticos e de reflexão pessoal, p. 77. 
sombrio" 51 .

Em um texto, atribuído a esta personagem, que transcrevo a seguir o frade e seus questionamentos existenciais alude à teologia agostiniana. Ei-la ${ }^{52}$ :

Por que sou tão infeliz? Por que metade de mim está irmanada com outra metade, a conquista de uma é a derrota da outra, e havendo derrota há sofrimento - o meu sofrimento em qualquer dos casos. Metade de mim é nobre e grandiosa, metade de mim é pequena e vil. Ambas são eu. Quando a parte de mim que é grandiosa triunfa, sofro porque a outra metade - que também é verdadeiramente eu próprio, não consegui alienar de mim - dói por isso. Quando a parte inferior de mim triunfa, a parte nobre sofre e chora. Lágrimas ignóbeis ou lágrimas nobres - tudo são lágrimas.

O representante clérigo das personas pessoanas, convive entre a necessidade de exprimir os valores morais cultivados no seio cristianismo, e exigido aos sacerdotes da instituição religiosa ao qual está vinculado, e seus desejos particulares, os quais apesar julgá-los vil, considera-os necessários, já que segundo ele "dói-me não ser totalmente bom".

\section{Fingimento: o derretimento de uma religiosidade sólida}

Fernando Pessoa era um fingidor, ele mesmo advertira. Sua compreensão de Religião ia além dos limites sociais estabelecidos. É o recurso da heteronomia que possibilita uma religiosidade, não una, visto que ele não é apenas uma pessoa, mas, pluriforme.

Zigmunt Bauman, em sua obra Modernidade Liquida defende a tese de que há uma nova modernidade chamada "modernidade fluída", caracterizada pela existência de uma mão invisível que desarticulou a sociedade pela ausência de padrões e referências. Tal fato provocou mudanças na condição humana, o que exige repensar os velhos conceitos que permeavam nossas análises. Para sustentar a sua tese, Bauman argumenta analisando cinco conceitos (emancipação, individualidade, tempo/espaço, trabalho, comunidade) que deveriam, na

51. Cf. Idem, ZENITH, R. Notas Prévias, introdução e comentários, p.7.

52. Cf. Cf. Idem, PESSOA [Maurice], p. 79. 
modernidade sólida, constituir um chão firme, entretanto, ao longo da história eles foram alterando-se e malogrando rigidez. Este cenário refletia uma mudança social a que denominou: modernidade líquida ${ }^{53}$.

Nas análises empreendidas por Bauman dos conceitos supra-mencionados, percebemos a descrição de características bem comuns ao nosso cotidiano. Seja a incerteza da vida diária; a insegurança na cidade; laços afetivos fugazes e constituídos de maneiras superficiais; excesso de informações. Interessa-me particularmente a noção de fluidez. Antes de discuti-la, penso ser prudente caminharmos por mais uma trilha.

Georg Simmel foi um expressivo pensador do fenômeno religioso, e é nestas análises que ele desenvolve sua reflexão sobre a religiosidade, ponto nodal desta pesquisa. $\mathrm{O}$ uso da designação religiosidade não é consenso, entretanto utilizo-a aqui no sentido de "uma dimensão humana, histórica e culturalmente determinada, que se abre à transcendência, mobiliza energias e se materializa em formas cognitivas e emocionais na construção de sentido para a totalidade de existência" ${ }^{54}$. Ao postular a humanidade da dimensão religiosa, Simmel revela a profundidade da sua natureza, isto é, a propriedade de se recriar permanentemente ao longo da história, seja nas manifestações culturais e/ou nas ações interindividuais.

Desse modo, o filósofo alemão assinala no fenômeno religioso uma dinâmica evolutiva. Esse processo parte de determinadas relações (sociais e psicológicas), que podem, ou não, tornar-se formalmente religiosas ${ }^{55}$ :

a base subjacente da categoria religiosa é fornecida pela marcante analogia entre o comportamento do indivíduo para com a divindade e o comportamento para com a sociedade. Um aspecto essencialmente importante é o senso de dependência.

Sob esta perspectiva, Simmel advoga um processo que se inicia com os

53. Cf. BAUMANN, Z. Modernidade Líquida, 2001.

54. Cf. Ibidem, Fernando Pessoa, escritos autobiográficos, automáticos e de reflexão pessoal apud Ribeiro, p. 116

55. SIMMEL, G. Essays on Religion, p.110; 156 
impulsos íntimos, passando pelas relações sociais e pelo sentimento religioso e vem abocar no fato religioso.

Dado o contexto fluído como o atual, em que prepondera a desregulação institucional e cresce o número de pessoas religiosas sem religião, a distinção entre religião e religiosidade mostra-se operacional ao sustentar-se na assertiva de que "a religião não cria a religiosidade, mas esta é que cria a religião" Danièle Hervieu-Léger, ao tratar as crenças contemporâneas, insere-se na vertente simmeliana. Assinala ${ }^{57}$ :

O religioso não se define unicamente através dos objetos sociais (as "religiões") nas quais se manifesta de modo compacto e concentrado. O religioso é uma dimensão transversal do fenômeno humano, que trabalha de modo ativo ou latente, explícito ou implícito, em toda a espessura da realidade social, cultural e psicológica, segundo modalidades próprias a cada uma das civilizações.

Caminhemos juntos. A primeira característica da modernidade é de dar ênfase a racionalidade, em todos os domínios da ação. Entretanto, a ciência ao avançar suscita novas interrogações, passível de constituir novos centros de irracionalidade. Ademais, "a racionalidade está longe de se impor de forma uniforme em todos os registros da vida social e sobre isso somos conscientes mais do que nunca" ${ }^{\prime \prime 8}$.

Uma outra característica é a autonomia do indivíduo-sujeito, capaz de construir o mundo em que ele vive e de engendrar, ele mesmo, as significações que dão sentido à sua própria existência. Além disto, é uma marca da modernidade um tipo particular de organização social, caracterizada pela diferenciação das instituições, especialização de diferentes domínios da atividade social. Obviamente, a autonomia desses domínios convive com a dependência.

O processo de emancipação está ancorado na idéia de "laicização" das sociedades modernas, isto é, a religião deixa de subsidiar os indivíduos e os

56. Idem, p. 150.

57. Cf. HERVIEU-LÉGER, D. Le pèlerin et le converti, p.19.

58. Idem, p. 30 
grupos com conjuntos de referências, normas, valores, símbolos que lhes permitam atribuir sentido à suas vidas e às suas experiências. Na modernidade, a religião deixa de ser um código de sentido que se impõe a todos. Contudo, as sociedades tradicionais não viviam sob império absoluto da religião. E além disso, nas sociedades modernas a crença e a participação religiosa são "matéria de escolha": são questões privadas, que resultam da consciência individual e que nenhuma "instituição religiosa ou política pode impor a ninguém" 59 .

O processo de secularização das sociedades modernas não se reduz unicamente a perda de espaço sociais e culturais da religião, com a qual é confundida comumente. Antes, ela combina de forma complexa o decréscimo da influência de grandes sistemas religiosos sobre uma sociedade - que reivindica sua plena capacidade de definir seu destino - e, a recomposição, sob nova configuração religiosa, que permitiram a esta sociedade considerar-se autônoma.

Deste modo, podemos - à semelhança de Hervieu-Léger - argumentar que a oposição entre contradições do presente e o horizonte de uma realização futura cria "espaços de esperas". Nestes emergem novas formas de religiosidades, ou novas configurações de modelos antigos, que permitem superar tal tensão. Se a solidez da modernidade rechaça a plausibilidade da religião. Seu derretimento, associado às incertezas deste novo paradigma - seja nomeado de modernidade líquida ou pós-modernidade, fez acentuar a busca da religião.

\section{(in)Conclusão: Uma bricolage das crenças?}

Tanto no caso da Religiosidade em Pessoa, quanto no contexto atual, não é o desinteresse religioso que caracteriza nossa sociedade, é sim, a configuração de uma crença que escapa às grandes religiões.

Na condição atual os indivíduos são tendentes à desregulação, isto é, subjetivam e individualizam suas crenças religiosas. E para além disso, bricolam seus sistema de crenças, fora de um sistema de crenças tradicionais. Tal bricolage liqüefaz as fronteiras entre comprometimentos religiosos. Portanto, a não ade-

59. Idem, p. 33. 
são a determinado projeto religioso propagado por uma instituição não significa não-crença, e sim, aponta para a diversificação da própria crença, essa configuração da religiosidade pessoal muitas vezes não é comportada pelas instituições religiosas.

Obviamente, isso não exclui - em alguns - a necessidade de expressar a crença individual comunitariamente. As identificações confessionais, mesmo tendo em mente a fragilidade dos laços sociais que compõem as comunidades na contemporaneidade, contribuem para a reafirmação de velhas garantias. 0 desafio para tal empreendimento é buscar a unidade desconsiderando as diferenciações e valorizando as semelhanças. Este desafio não deve fomentar a construção de fronteiras fechadas, pois como lembrou Orivaldo Pimentel Lopes Jr.: "Quando tomamos a identidade como forma de narcisismo, logo nos apressamos a rejeitar as companhias que não nos alimentam o ego. Em vez disso, a identidade serve como ferramenta para o diálogo, coisa impossível de acontecer no gueto" ${ }^{60}$.

Para Bauman, a comunidade é a promessa de "um porto seguro para os navegantes perdidos no mar turbulento da mudança constante, confusa e imprevisível". Minha hesitação consiste em ser esse um sonho de pureza sectário, que opera segundo a distinção entre nós e eles, apartando tudo o que se considera estranho. Como ocorre nos fundamentalismos, sejam eles condomínios fechados ou nacionalismos.

Advogo que a religiosidade em Pessoa, fio condutor perseguido ao longo desse trabalho, é uma religiosidade líquida, isto é, uma versão privativa e individualizada da crença religiosa. Ele próprio, na voz de Álvaro de Campos, afirmara no poema Passagem das Horas: "E há em cada canto da minha alma um altar a um deus diferente". Assim como os sólidos que se derreteram na fase líquida da modernidade foram os elos que entrelaçaram os desígnios individuais em projetos e ações coletivas, no processo de liqüefação da religiosidade atual, os patrimônios simbólicos das religiões tradicionais entrelaçam-se com aspectos

60. LOPES Jr, O. O Espelho de Procrusto: Estudos religionistas, igrejas evangélicas e conhecimento científico, p. 162 
e/ou concepções de outros universos religiosos (não-tradicionais).

A liquefação dos sólidos expõe um tempo de desapego e provisoriedade. Uma religiosidade fluída e maleável remete a uma sensação de leveza - talvez uma insustentável leveza, que pode ser associada à liberdade individual.

Este trabalho é inconcluso. Em parte por não ser possível neste artigo, mergulhar em todos os heterônimos e/ou semi-heterônimos de Fernando Pessoa, fi-lo com um pouco mais de vagar noutro trabalho ${ }^{61}$. Contudo, é possível perceber elementos que confirmam, mesmo noutras personas do Pessoa uma intensa pluralidade religiosa. Ou, como prefiro dizer, Fernando Pessoa inaugurou uma religiosidade líquida ${ }^{62}$.

Envio: 29 mar. 2011

Aceite: 15 mai. 2011

\section{Referências}

ABDO, Sandra. Fernando Pessoa: Poeta cético?. Tese de Doutoramento apresentada a Faculdade de Filosofia Letras e Ciências Humanas da Universidade de São Paulo, 2002.

ALMEIDA, Maria da C. Complexidade, do casulo à borboleta. IN: CASTRO, Gustavo; Et. al. Ensaios de Complexidade. Porto Alegre: Sulina, 1997. P. 25-46.

ANTUNES, Alfredo. Saudade e Profetismo em Fernando Pessoa. Braga: Publicações da Faculdade de Filosofia de Braga, 1983.

AZEVEDO, Murilo Nunes. Fernando Pessoa o teósofo. IN: BLAVATSKY, Helena. A voz do Silêncio. (introdução). Tradução de Fernando Pessoa. Rio de Janeiro: Civilização Brasileira, 1972.

BACHELARD, Gaston. A chama de uma vela. Rio de Janeiro: Bertrand Brasil, 1989.

. A poética do devaneio. Trad.: Antônio de Pádua Danesi. São Paulo: Martins Fontes, 1988.

. A poética do espaço. Trad.: Antônio de Pádua. São Paulo: Martins Fontes, 1993.

61. A Religiosidade em Pessoa foi temática da minha dissertação de mestrado que foi publicado em 2008 cf. SILVA, Anaxsuell F. A religiosidade em Pessoa. São Paulo: Blucher, 2008.

62. Idem, p. 103. 
Fragmentos de uma poética do fogo. Trad.: Norma Telles. São Paulo: Brasiliense, 1990.

O direito de sonhar. Trad.: José Américo Pessanha. São Paulo: Difel, 1985.

BAUMANN, Zygmunt. Modernidade Líquida. Rio de Janeiro: Jorge Zahar Editor, 2001.

CAMPBELL, Joseph. O poder do mito. São Paulo: Palas Athena, 1990.

COSTA, Dalila P. da. O esoterismo em Fernando Pessoa. Porto: Ed. Lello \& Irmão, 1978. $2^{\mathrm{a}}$ ed.

ELIADE, Mircea. O sagrado e o profano. São Paulo: Martins Fontes, 1992. Tratado de história das religiões. São Paulo: Martins Fontes, 2002.

EPICURO. et al. Antologia de textos. São Paulo: Abril Cultural, 1973.

GAMA, Rinaldo. 0 guardador de Signos: Caeiro em Pessoa. São Paulo: Editora Perspectiva, 1985.

GULLAR, Ferreira. In: Folha de São Paulo, Caderno Mais!, 10 de novembro de 1996.

HERMANN, Jacqueline. No reino do desejado: a construção do sebastianismo em Portugal (séculos XVI e XVII). São Paulo, 1998.

HERVIEU-LÉGER, Daniele. Le pèlerin et le converti. Paris: Flammarion, 1999.

HOURCADE, Pierre. Temas da literatura portuguesa. Lisboa: Moraes, 1978.

LÉVI-STRAUS, Claude. Antropologia Estrutural. Rio de Janeiro: Tempo Brasileiro, 1993.

MEGIANNI, Ana Paula Torres. O jovem encantado: aspectos da construção e personificação do mito messiânico português. (Dissetação de Mestrado). Faculdade de História da USP. São Paulo, 1995.

MESQUITA, André. Fernando Pessoa: o ocultismo na ótica poética. Rio de Janeiro: Uapê, 1996.

MOISÉS, Carlos Felipe. Fernando Pessoa: almoxarifado de mitos. São Paulo: Escrituras Editora, 2005.

LOPES Jr., Orivaldo P. O Espelho de Procrusto: Estudos religionistas, igrejas evangélicas e conhecimento científico. Tese doutoral. São Paulo: PUCSP, 2003.

NOGUEIRA, Lucila. A lenda de Fernando Pessoa. Recife: Associação de Estudos Portugueses João Emerenciano, 2003.

ORDOÑEZ, Andrés. Fernando Pessoa, um místico sem fé. Tradução Sônia 
Regina Cardoso. Rio de Janeiro: Nova Fronteira, 1994.

PAZ, Octávio. $O$ arco e a lira. Trad. Olga Savary. Rio de Janeiro: Nova Fronteira, 1982.

PERRONE-MOISÉS, Leyla. Fernando Pessoa: aquém do eu, além do outro. São Paulo: Martins Fontes, 1990. 2a ed.

Introdução ao Desassossego In: PESSOA, Fernando. Livro do Desassossego. São Paulo: Editora Brasiliense, 1986.

PESSOA, Fernando. Obras Poética. Rio de Janeiro: Nova Aguilar, 1966.

. Páginas íntimas e de auto-interpretação. Textos estabelecidos e prefaciados por Georg Rudolf Lind e Jacinto Prado Coelho. Lisboa: Edições Ática, 1966.

. Textos Filosóficos. Org. Antônio Pina Coelho. Lisboa: Ática, 1968.

. Fiç̧ões do interlúdio/1: Poemas completos de Alberto Caeiro. Rio de Janeiro: Nova Fronteira, 1980.

. Fiç̧ões do interlúdio / 2-3: Odes de Ricardo Reis; Para lém do outro Oceano de Coelho Pacheco. 4a ed.Rio de Janeiro: Nova Fronteira,1983.

Poemas. (Org. de Cleonice Berardinelli). Rio de Janeiro: Nova Fronteira, 1985.

. Livro do desassossego. São Paulo: Editora Brasiliense, 1986.

. O Banqueiro anarquista e outras prosas. São Paulo: Cultrix; Editora da Universidade de São Paulo, 1988.

. Mensagem. São Paulo: Companhia das Letras, 1998

. Obras em Prosa. Rio de Janeiro: Nova Aguilar, 1998.

A educação do Estóico / Barão de Teive. 2a ed. Lisboa: Assírio\&Alvim, 2001.

Aforismos e afins. Tradução Manuela Rocha. São Paulo: Companhia das Letras, 2006a.

. Escritos autobiográficos, automáticos e de reflexão pessoal. [Tradução Manuela Rocha]. São Paulo: A Girafa Editora, 2006b. 2006c.

As origens e essência da Maçonaria. São Paulo: Landy Editora,

QUADROS, Antônio. Fernando Pessoa: vida e personalidade de um gênio. $2^{\text {a }}$ ed.Lisboa: Ed. Quixote,1984.

SAFRA, Gilberto. Fernando Pessoa e a condição humana. Aula ministrada em 
11/05/2005. Disponível em DVD. São Paulo: Edições Sobornost, 2005. SARAMAGO, José. In: JL. Lisboa, 26 de novembro de 1985.

SILVA, Anaxsuell F. A religiosidade em Pessoa. São Paulo: Blucher, 2008.

GOMES, Ana Laudelina Ferreira; DANTAS, Alexsandro Galeno Araújo; CICCARONI, Celeste (Orgs.). Cronos. Revista do Programa de Pós-graduação em Ciências Sociais da UFRN. Dossier Gaston Bachelard. Natal, v. 4, n.1/2, jan./dez. 2003.

SILVA, Anaxsuell F. A religiosidade em Pessoa. São Paulo: Blucher, 2008.

SIMMEL, G. Essays on Religion. Yale: Yale University Press/Durham, 1997.

SIMOES, João Gaspar. Vida e obra de Fernando Pessoa - história de uma geração. Lisboa: Livraria Bertrand, 1951.

TABUCCHI, Antonio. Pessoana mínima. Coleção Temas Portugueses. Imprensa Nacional/Casa da Moeda, 1984.

ZENITH, Richard. Notas Prévias, introdução e comentários. In: Fernando Pessoa, escritos autobiográficos, automáticos e de reflexão pessoal. Trad.: Manuela Rocha. São Paulo: A girafa editora, 2006. 